\title{
Optimizing Eastern Gamagrass Forage Harvests Using Growing Degree Days
}

\author{
Tim L. Springer, Stacey A. Gunter, Jason J. Goldman, Corey A. Moffet \\ Southern Plains Range Research Station, USDA-Agricultural Research Service, Woodward, OK, USA \\ Email: tim.springer@ars.usda.gov
}

How to cite this paper: Springer, T.L., Gunter, S.A., Goldman, J.J. and Moffet, C.A. (2016) Optimizing Eastern Gamagrass Forage Harvests Using Growing Degree Days. Agricultural Sciences, 7, 710-715. http://dx.doi.org/10.4236/as.2016.710066

Received: September 13, 2016

Accepted: October 23, 2016

Published: October 26, 2016

Copyright $\odot 2016$ by authors and Scientific Research Publishing Inc. This work is licensed under the Creative Commons Attribution International License (CC BY 4.0).

http://creativecommons.org/licenses/by/4.0/

\begin{abstract}
Tripsacum dactyloides (L.) L., commonly known as eastern gamagrass, is useful for grazing, stored forage, soil amelioration and conservation, and as a biofuel feedstock. Our goal was to calculate accumulated growing degree days (GDD) from existing datasets collected for eastern gamagrass forage production experiments in northwestern Oklahoma, and discuss the use of GDD, instead of calendar harvest dates, in the production of eastern gamagrass forage. Growing degree days were calculated from 1 January each year using the "optimum day method". For 10 harvest years, the first eastern gamagrass harvest required $690 \pm 26$ cumulative GDD. Based on long-term weather data from Woodward, Oklahoma, this would place the first harvest on or near 1 June. The second harvest required $635 \pm 27$ cumulative GDD which would place the second harvest on or near 15 July and the third harvest required $690 \pm 23$ cumulative GDD placing it on or near 30 August. Each of the 30 harvest required an average of $670 \pm 15$ cumulative GDD. Using GDD to predict harvest events is a useful tool that forage producer can use in the production of eastern gamagrass forage in the USA and possibly elsewhere.
\end{abstract}

\section{Keywords}

Eastern Gamagrass, Tripsacum dactyloides, Growing Degree Days

\section{Introduction}

Tripsacum dactyloides (L.) L., commonly known as eastern gamagrass, is a perennial, native, warm-season forage grass distributed throughout the eastern, central, and southern USA [1]. It is useful for grazing, stored forage, soil amelioration and conservation, and as a biofuel feedstock [2]. In the mid-1970's, preliminary experiments were conducted at the USDA-ARS Southern Plains Range Research Station, Woodward, OK, to evaluate the effects of harvest frequency and clipping height on forage dry-matter 
yield and nutritive value of eastern gamagrass (Dewald, unpublished data, 1975). These experiments were conducted by the late Mr. Chet Dewald to gain a general knowledge about the crop and to improve the selection and breeding of eastern gamagrass. The information gained from these experiments was generally reported at eastern gamagrass conferences, workshops, and producer groups, but has not been published widely. For example, Mr. Dewald reported in a discussion section regarding the planting and uses of eastern gamagrass that, "In Woodward, Oklahoma we find that if we cut it (eastern gamagrass) June 1, July 15, and the last days of August, we've got our most TDN (total digestible nutrients) per acre. Now when we cut on 30 day intervals, we had our highest protein percentages. When we cut on 60 day intervals, we had our highest tonnage. But the highest TDN per acre was found using 45 day intervals [3]". Although information like this was not reported in the mainstream journals, it became the starting point for more detailed agronomic research of eastern gamagrass.

For example, Douglas et al. [4] reported the effects of clipping frequency and nitrogen rates on the yield and quality of eastern gamagrass forage for the southeastern USA. They found an inverse relationship between clipping frequency and dry-matter yield, higher forage quality with increasing clipping frequency, and a maximum forage yield at a fertilization rate of $450 \mathrm{~kg} \cdot \mathrm{ha} \mathrm{a}^{-1}$ of N. Brejda et al. [5] harvested eastern gamagrass at a frequency of 4- and 6-weeks in Missouri. They reported that three or four harvests were possible during the growing season using a 4-week interval and two or three harvests were possible using a 6 -week harvest interval. Crude protein concentration averaged $131 \mathrm{~g} \cdot \mathrm{kg}^{-1}$ using a 4-week harvest interval compared to $97 \mathrm{~g} \cdot \mathrm{kg}^{-1}$ using a 6-week harvest interval. Total forage yields were higher for a 6 -week versus a 4 -week harvest interval.

Many warm-season plants are dependent on adequate and timely rainfall and the accumulation of heat units [6], and eastern gamagrass is no exception. The goal of this paper is to calculate accumulated Growing Degree Days (GDD) from existing datasets collected for eastern gamagrass forage production experiments at the Southern Plains Range Research Station in Woodward, Oklahoma, and discuss the use of GDD, instead of calendar harvest dates, in the forage production management of eastern gamagrass in the USA.

\section{Materials and Methods}

All experiments were conducted at the USDA-ARS Southern Plains Range Research Station, Woodward, OK $\left(36^{\circ} 25^{\prime} \mathrm{N}, 99^{\circ} 24^{\prime} \mathrm{W}\right.$, elevation $\left.615 \mathrm{~m}\right)$. The first experiment, conducted 1978-1982, reported the effects of plant population density on forage yield of eastern gamagrass [7]. This experiment was planted on a Carey silt loam (Fine silty, mixed, superactive, thermic Typic Argiustoll) soil with ramets of accession WW-1000. Accession WW-1000 was a locally adapted strain of eastern gamagrass collected on the Southern Plains Range Research Station in 1971 and is similar to other natural occurring populations of eastern gamagrass found in western Oklahoma and the Texas panhandle. 
The second experiment, conducted 2001-2003, reported the effects of plant genotype, growth environment, and genotype-by-environment interactions on the fermentation characteristics of eastern gamagrass and other native, warm-season grasses in relation to their use as feedstocks for biofuels [8]. This experiment was planted on an Eda loamy fine sand (Mixed, thermic Lamellic Ustipsamments) soil. Eastern gamagrass cultivars and experimental lines used in this experiment included, "Pete" [9], FT-II ("Verl") and FT-IV [10] [11], FGT-1 [12] and FT 94-8.

The third experiment, conducted 2008-2009, compared eastern gamagrass cultivars and germplasm lines for biomass production [13]. This experiment was planted on a Devol fine sandy loam (coarse-loamy, mixed, superactive, Thermic Typic Haplustalfs) soil. Eastern gamagrass cultivars and experimental lines used in this experiment included, Pete, Verl, “Bumpers" [14], "Highlander” [15], and experimental lines GR, GM, and D1.

In general for all three experiments, plants were grown from seeds in the greenhouse and were transplanted into replicated field plots. During the establishment year, plots were maintained weed-free by hoeing and plants that died after transplanting were replaced. Plots were burned and herbicide was applied in March each year. Plots were fertilized with nitrogen and forage was harvested three times each year when plants were in the boot-stage of growth. Specific details about plot management, irrigation, rainfall, fertilization, and weed control is presented in the published research [7] [8] [13].

Local weather data were used to calculate the accumulated GDD for each harvest. The Southern Plains Range Research Station has operated a weather station since 1914 and it is located within a $500 \mathrm{~m}$ radius of where these three experiments were conducted. Growing degree days were calculated from 1 January each year using the "optimum day method" [16].

$$
\mathrm{GDD}=\left(T_{\max }+T_{\min }\right) / 2-T_{\text {base }}
$$

where $T_{\max }$ in Equation (1) is the maximum daily temperature and is set to $30^{\circ} \mathrm{C}$ when temperatures exceed $30^{\circ} \mathrm{C}$, and $T_{\min }$ is the minimum daily temperature and is set to $10^{\circ} \mathrm{C}$ when temperatures fall below $10^{\circ} \mathrm{C}$, and $T_{\text {base }}$ is the base temperature for the organism. A base temperature of $10^{\circ} \mathrm{C}$ was used for eastern gamagrass. Also, the daily GDD was set to zero when the calculated GDD was less than zero. Daily GDD were then summed from 1 January to calculate cumulated GDD for the first harvest date. Daily GDD were cumulated from the first harvest date until the second harvest date for the second harvest date cumulated GDDs, and likewise for the third harvest. The cumulated GDD for the 10 harvest years, representing 30 harvests were averaged using the means procedure and a standard error were calculated for each mean [17].

\section{Results}

The typical climate at Woodward, Oklahoma, USA is characterized by hot summers, cold winters, and little rainfall. The length of the growing season at Woodward is ap- 
proximately $200 \mathrm{~d}$ [18], and the long-term average (LTA) precipitation is $622 \mathrm{~mm}$ (LTA, 99 year record at the Southern Plains Range Research Station). The LTA growing-season (1 April through 30 September) and dormant-season (1 October through 31 March) precipitation is $434 \mathrm{~mm}$ and $188 \mathrm{~mm}$, respectively.

For the 10 harvest years, the first eastern gamagrass harvest required $690 \pm 26$ cumulative GDD. Based on long-term weather data from Woodward, Oklahoma this would place the first harvest on or near 1 June. The second harvest required $635 \pm 27$ cumulative GDD which would place the second harvest on or near 15 July and the third harvest required $690 \pm 23$ cumulative GDD placing it on or near 30 August. Each of the 30 harvest required an average of $670 \pm 15$ cumulative GDD. This would place the first, second, and third harvests on or near 30 May, 16 July, and 30 August each year, respectively.

\section{Discussions}

Degree day accumulation has long been used to predict the initiation of plant growth and development [19]. Similarly, the concept of GDD has been useful for predicting insect emergence in field crops [20], and the interdependency of insects with field crops [21]. For example, Carlson and Gage [21] found the average time from planting to silking in corn (Zea may L.) was between 710 - 825 cumulated GDD for the cultivars studied. They also determined that the first generation large larvae of the European corn borer [Ostrinia nubilalis (Hübner)] peaked at 650 cumulated GDD and adult emergence peaked at 900 cumulated GDD. Similarly, Springer et al. [22] determined the number of the GDD for the life stages of stalk borer (Diatraea mitteri Solis [23]) in eastern gamagrass and found that it took approximately 900 cumulated GDD for the insect to complete its life cycle.

Application of the use of GDD takes the guess work out of the harvest management of eastern gamagrass. Each harvest interval requires approximately 670 cumulative GDD. This value should be useful anywhere eastern gamagrass is grown because plant development depends on the accumulation of specific quantities of heat. Therefore, it should be possible to predict when growth events should occur during a growing season regardless of differences in temperatures from year to year. However, it is possible that variation may exist among genotypes of eastern gamagrass for predicted life events using GDD, but chances are small considering the number of genotypes tested in our experiments.

Eastern gamagrass requires a 6 to 8 -week rest period prior to a killing frost to allow shoots enough time to store carbohydrates and nutrients that aid in their winter survival. The average frost date at Woodward, Oklahoma is 15 October. Thus, the first week of September is the latest that a harvest should be made at Woodward.

In theory, it is possible to obtain five forage harvests near Brooksville, Florida, USA. Based on mean daily temperature data, the first harvest would be at 675 cumulative GDD ( 3 April) and the fifth harvest would be at 3370 cumulative GDD (1 October). The average frost date for this area of Florida is 9 December. The interval from 1 Octo- 
ber until 9 December would be ample time for plants to acquire sufficient nutrients to overwinter. In theory, five harvests are possible in central Florida; but, this is dependent on precipitation. The estimates of cumulative GDD are based on continuous plant growth. If drought occurs during the harvest interval and plants cease to grow, then the accumulation of GDD should cease as well. Once plant growth begins again, the accumulation of GDD could begin again. Accessing GDDs is another useful tool that forage producer can use in the production and management of eastern gamagrass in the USA and possibly elsewhere.

\section{Acknowledgements}

Funding for this research was provided by USDA-ARS. All programs and services of the USDA are offered on a nondiscriminatory basis, without regard to race, color, national origin, religion, sex, age, marital status or handicap. Mention of a trademark or a proprietary product does not constitute a guarantee or warranty of the product by USDA and does not imply approval to the exclusion of other suitable products.

\section{References}

[1] Barkworth, M.E., Anderson, L.K., Carpels, K.M., Long, S. and Piep, M.B. (2007) Manual of Grasses of North America. Utah State University Press, Logan.

[2] Springer, T.L. and Dewald, C.L. (2004) Eastern Gamagrass and Other Tripsacum Species. In: Moser, L.E., Sollenberger, L.E. and Burson, B.L., Eds., $\mathrm{C}_{4}$ [Warm-Season Grasses]. ASA, CSSA, and SSSA, Madison, 955-973.

[3] Dewald, C.L. (1990) Discussion: Planting and Using Eastern Gamagrass. In: Eastern Gamagrass Conference Proceedings, Poteau, 23-25 January 1989, 61.

[4] Douglas, J.L., Adams, F.M., Young, J.L. and Bell, T.L. (1993) Effects of Clipping Frequency and Nitrogen Rates on Yield and Quality of Eastern Gamagrass. In: Eastern Gamagrass Workshop Proceedings, Manhattan, Kansas, 13-14 October 1993, 38.

[5] Brejda, J.J., Brown, J.R., Lorenz, T.E., Henry, J., Reid, J.L. and Lowry, S.R. (1996) Eastern Gamagrass Responses to Different Harvest Intervals and Nitrogen Rates in Northern Missouri. Journal of Production Agriculture, 9, 130-135.

http://dx.doi.org/10.2134/jpa1996.0130

[6] Cherney, J.H. and Volenec, J.J. (1992) Forage Evaluation as Influenced by Environmental Replication: A Review. Crop Science, 32, 841-846. http://dx.doi.org/10.2135/cropsci1992.0011183X003200040001x

[7] Springer, T.L., Dewald, C.L, Sims, P.L. and Gillen, R.L. (2003) How Does Plant Population Density Affect the Forage Yield of Eastern Gamagrass? Crop Science, 43, 2206-2211. http://dx.doi.org/10.2135/cropsci2003.2206

[8] Weimer, P.J. and Springer, T.L. (2007) Fermentability of Eastern Gamagrass, Big Bluestem and Sand Bluestem Grown Across a Wide Variety of Environments. Bioresource Technology, 98, 1615-1621. http://dx.doi.org/10.1016/j.biortech.2006.06.003

[9] Fine, G.L., Barnett, F.L., Anderson, K.L., Lippert, R.D. and Jacobson, E.T. (1990) Registration of "Pete" Eastern Gamagrass. Crop Science, 30, 741-742. http://dx.doi.org/10.2135/cropsci1990.0011183X003000030057x

[10] Dewald, C.L., Taliaferro, C.M. and Dunfield, P.C. (1992) Registration of Four Fertile Trip- 
loid Germplasm Lines of Eastern Gamagrass. Crop Science, 32, 504. http://dx.doi.org/10.2135/cropsci1992.0011183X003200020057x

[11] Springer, T.L., Dewald, C.L., Sims, P.L., Gillen, R.L., Louthan, V.H., Cooper, W.J., Taliaferro, C.M., Maura Jr., C., Pfaff, S., Wynia, R.L., Douglas, J.L., Henry, J., Bruckerhoff, S.B., Van Der Grinten, M., Salon, P.R., Houck Jr., M.J. and Esquivel, R.G. (2006) Registration of "Verl" Eastern Gamagrass. Crop Science, 46, 477-478.

http://dx.doi.org/10.2135/cropsci2005.05-0043

[12] Dewald, C.L. and Kindiger, B. (1996) Registration of FGT-1 Eastern Gamagrass Germplasm. Crop Science, 36, 219. http://dx.doi.org/10.2135/cropsci1996.0011183X003600010057x

[13] Goldman, J.J. and Springer, T.L. (2011) Agronomic Performance of Eastern Gamagrass Cultivars and Experimental Germplasm Grown on the Southern Plains. Native Plants Journal, 12, 1-7. http://dx.doi.org/10.3368/npj.12.2.100

[14] USDA, Natural Resources Conservation Service (2006) Notice of Release of "Bumpers" Eastern Gamagrass. http://www.plant-materials.nrcs.usda.gov/pubs/arpmcrn5878.pdf

[15] Grabowski, J.M., Douglas, J.L., Lang, D.J. and Edwards, S.D. (2005) Registration of "Highlander” Eastern Gamagrass. Crop Science, 45, 412-413. http://dx.doi.org/10.2135/cropsci2005.0412

[16] Barger, G.L. (1969) Total Growing Degree Days. Weekly Weather and Crop Bulletin, 56, 10.

[17] SAS Institute Inc. (2010) SAS/STAT ${ }^{\circledast}$ User’s Guide. Version 9.22, Cary, NC. http://support.sas.com/documentation/cdl/en/statug/63347/HTML/default/viewer.htm\#stat ug_intro_sect010.htm

[18] Kincer, J.B. (1941) Climate and Weather Data for the United States. In: Climate and Man, 1941 Yearbook of Agriculture, US Government Printing Office, Washington DC, 685-1228.

[19] Wang, L.M. (1960) A Critique of the Heat Unit Approach to Plant Response Studies. Ecology, 41, 785-790. http://dx.doi.org/10.2307/1931815

[20] Knutson, A.E., Jackson, J.A., Cronholm, G.B., Ng, S.-S., Davis, F.M. and Morrison, W.P. (1989) Temperature-Dependent Model for Predicting Emergence of Adult Southwestern Corn Borer (Lepidoptera: Pyralidae) in Texas. Journal of Economic Entomology, 82, 12301236. http://dx.doi.org/10.1093/jee/82.4.1230

[21] Carlson, J.D. and Gage, S.H. (1989) Influence of Temperature upon Crop and Insect Pest Phenologies for Field Corn and the Role of Planting Date upon Their Interrelationships. Agricultural and Forest Meteorology, 45, 313-324. http://dx.doi.org/10.1016/0168-1923(89)90051-8

[22] Springer, T.L., Puterka, G.J., Maas, D.L. and Thacker, E.T. (2011) The Southern Cornstalk Borer (Diatraea crambidoides (Grote), Lepidoptera: Crambidae) a New Pest of Eastern Gamagrass (Tripsacum dactyloides (L.) L., Poaceae). Journal of the Kansas Entomological Society, 84, 209-216. http://www.bioone.org/doi/full/10.2317/JKES100907.1 http://dx.doi.org/10.2317/JKES100907.1

[23] Solis, M.A., Metz, M.A., Scheffer, S.J., Lewis, M.L., Kula, R.R. and Springer, T.L. (2015) A New Cryptic Species of Diatraea (Lepidoptera: Crambidae: Crambinae) Feeding on Eastern Gama Grass and a Novel Host Association with a Braconid (Hymenoptera) in the United States. Annals of the Entomological Society of America, 108, 648-659. http://dx.doi.org/10.1093/aesa/sav049 
Submit or recommend next manuscript to SCIRP and we will provide best service for you:

Accepting pre-submission inquiries through Email, Facebook, LinkedIn, Twitter, etc. A wide selection of journals (inclusive of 9 subjects, more than 200 journals)

Providing 24-hour high-quality service

User-friendly online submission system

Fair and swift peer-review system

Efficient typesetting and proofreading procedure

Display of the result of downloads and visits, as well as the number of cited articles

Maximum dissemination of your research work

Submit your manuscript at: http://papersubmission.scirp.org/

Or contact as@scirp.org 